University of Nebraska - Lincoln

DigitalCommons@University of Nebraska - Lincoln

Faculty Publications from the Harold W. Manter Laboratory of Parasitology

1984

\title{
Helminth Parasites of the Endangered Houston Toad, Bufo houstonensis Sanders, 1953 (Amphibia, Bufonidae)
}

\author{
Robert A. Thomas \\ Louisiana Nature Center \\ Steven A. Nadler \\ University of California - Davis, sanadler@ucdavis.edu \\ W. Lynn Jagers \\ Texas A \& M University - College Station
}

Follow this and additional works at: https://digitalcommons.unl.edu/parasitologyfacpubs

Part of the Parasitology Commons

Thomas, Robert A.; Nadler, Steven A.; and Jagers, W. Lynn, "Helminth Parasites of the Endangered Houston Toad, Bufo houstonensis Sanders, 1953 (Amphibia, Bufonidae)" (1984). Faculty Publications from the Harold W. Manter Laboratory of Parasitology. 699.

https://digitalcommons.unl.edu/parasitologyfacpubs/699

This Article is brought to you for free and open access by the Parasitology, Harold W. Manter Laboratory of at DigitalCommons@University of Nebraska - Lincoln. It has been accepted for inclusion in Faculty Publications from the Harold W. Manter Laboratory of Parasitology by an authorized administrator of DigitalCommons@University of Nebraska - Lincoln. 


\section{Helminth Parasites of the Endangered Houston Toad, Bufo houstonensis Sanders, 1953 (Amphibia, Bufonidae)}

Robert A. Thomas, Louisiana Nature Center, 11000 Lake Forest Blvd., New Orleans, Louisiana 70127; Steven A. Nadler, Department of Tropical Medicine and Medical Parasitology, Louisiana State University Medical Center, New Orleans, Louisiana 70112; and W. Lynn Jagers, Department of Biology, Texas A \& M University, College Station, Texas 77843

The Houston toad, Bufo houstonensis Sanders, has an extremely restricted range in southeastern Texas, being known historically from 6 counties with viable populations remaining in only 2 . Due to its relative rarity and federally protected status as an endangered species, its parasites have received attention only once. Harwood (1932, Proc. U.S. Natl Mus. 81: 1-71) identified 2 Harris 
County specimens of this toad as $B$. terrestris and reported Cosmocercoides dukae (Oxyuridae) in both and Oswaldocruzia pipiens (Diaphanocephalidae) in 1 . In the course of ecological studies on the Houston toad, additional information on its parasitic helminths has been acquired.

Seventeen preserved specimens of $B$. houstonensis from the following institutions were used in the study: Strecker Museum, Bryce C. Brown (BCB) Collection, Baylor University, Waco, Texas, and the Texas Natural History Collection (TNHC), University of Texas, Austin. The sample represented 2 localities: Bastrop County (TNHC 35536-37) and Harris County (TNHC $25628,25630,34741$; BCB 5441, 5457-59, 5461$62,5678-79,5683,5690-91,5693)$. Additionally, parasites were examined from a series of toads collected as eggs and tadpoles in Bastrop County and raised in the Houston Zoological Gardens. The digestive tract, lungs, heart, gall bladder, liver, and coelomic cavity of each specimen were examined. Most of the parasites were mounted temporarily for identification, then returned to vials of $70 \%$ isopropyl alcohol and remain with the host voucher specimen. Brachycoelium storeriae from 2 specimens (BCB 5441 and 5457) were stained with Semichons acetocarmine and remain mounted in Canada balsam. Type material of the following species was used to verify identifications: Physaloptera ranae (USNM Helm. Coll. 50789), Cosmocercoides dukae (USNM Helm. Coll. 8001), and Brachycoelium storeriae (USNM Helm. Coll. 30873).

Only 2 specimens (TNHC 25628 and 25630) were devoid of helminths. Those found in the remaining 15 toads provide new host records for 3 species: 2 nematodes, Physaloptera ranae (Spiruridae) in the stomach of 1 host from Harris County, and Rhabdias ranae (Rhabdiasidae) from the lungs of 3 hosts from that county; and the trematode, Brachycoelium storeriae (Brachycoe- liidae) in the small intestines of 1 specimen from Bastrop County and 2 from Harris County. Other helminths found included: $O$. pipiens in the stomach and small intestine of 13 Harris County toads; $C$. dukae from the intestine and rectum of 9 hosts representing both counties, and unidentifiable tetrathyridea in the gall bladder and common mesentaries of a specimen from Harris County and in the same tissues plus heart and liver of a Bastrop County toad. Neither $O$. pipiens nor $P$. ranae was found in the captive reared toads from Bastrop County but $R$. ranae was abundant in them.

None of the parasites found are unique to the Houston toad or the family Bufonidae. Bufo americanus, the presumed nearest relative of $B$. houstonensis, shares most of these parasites (Rosen and Manis, 1976, J. Parasit. 62: 833-834; Baker, 1977, Can. J. Zool. 55: 104-105; Baker 1978, Can. J. Zool. 56: 1026-1031; Baker, 1978, J. Parasit. 64: 765-766; Ashton and Rabalais, 1978, Proc. Helminth. Soc. Wash. 45: 141-142). Instead of Rhabdias ranae, $B$. americanus is infected with $R$. americanus $(=R$. bufonis of Ashton and Rabalais, loc. cit.; fide Baker, 1978, Can. J. Zool. 56: 2127-2141). Other parasites reported from B. americanus are Megalodiscus temperatus, Megalodiscus rankini, Ostiolum medioplexus, Haematoloechus similiplexus, an unidentified echinostome, and unidentified metacercariae (Rosen and Manis, loc. cit.; Ulmer, 1970, Am. Midl. Nat. 83: 38-64).

For the loan of specimens, we thank Bryce C. Brown and David Lintz, Strecker Museum; Robert F. Martin, Texas Natural History Collection, Terry L. Blasdel, Houston Zoological Gardens; Thomas M. Craig, Texas A \& M University School of Veterinary Medicine; and J. Ralph Lichtenfels, National Parasitological Collection. This study was accomplished under authority of U.S. Fish and Wildlife permit PRT 2-2588. 